\title{
LEVERAGE IMPACTS ON AGRO-INDUSTRIAL COMPANY INVESTMENTS
}

\author{
Nugroho Ahmad Cahyo* \\ Ministry of Industry, Indonesia \\ Firdaus Muhammad, Andati Trias, Irawan Tony \\ Bogor Agricultural University, Indonesia \\ *E-mail: ac.nugroho999@gmail.com
}

\begin{abstract}
Agro-industry has an important role in Indonesian economic growth. One of the crucial constraints in agro-industry investments in developing country is due to limited access to investment fund. This research was aimed to analyze the impacts of leverage on the agroindustrial company investments. The research used financial report data of the manufacturing industries on agro-industrial bases registered in Indonesian Stock-Exchange from 2007 to 2016. The data were analyzed using panel data regression analysis. The results of the research showed that the leverage influenced negatively on the agro-industrial companies. Cash flow has a negative impact on the company investments, which shows the existence of financial constraints when the company decide to invest.
\end{abstract}

\section{KEY WORDS}

Agroindustry, investment, leverage, Tobin-Q.

Agro-industry has an important role in Indonesian economic growth. Based on the Indonesian Republic Regulation number 14, 2015 concerning National Industry Development Master Plan in year 2015-203, the upstream agro-industry is one of the government's ten prioritized industries (Ministry of Industry 2015). Agro-industry contributions are relatively dominant to manufacturing industries as a whole and to national economic growth. The growth of agro-industry sector until the fourth quarter 2015 reached 5.82 percent. The contribution of agro-industry sector to national GDP up to the fourth quarter 2015 was 8.26 percent, and its contribution to non-oil processing industries was 45.42 percent. Furthermore, up to the fourth quarter 2015 agro-industry managed to employ 1.612 workers. When seen from domestic investments (PMDN), this sector until the fourth quarter 2015 reached 32.25 trillion rupiah with 1076 industry business permits, while from the foreign investments (PMA) it reached US\$ 10.15 billion with 1634 industrial business permits (Ministry of Industry 2016).

In line with that, the policy of increased export, investments, and tax incentive in agroindustry sector has reduced poverty level and improved household income distribution (Susilowati, 2007). Agro-industry is one of the development policies that can trigger national economic sector and enhance economic growth. The agro-industry development policies are, among others, policy on investments, technology and agro-industry location that needs to be primarily considered (Yusdja and lqbal 2002). One of the crucial constraints in agro-industry is investments in the field of agro-industry has not developed yet, which is due to limited incountry investment fund. Besides, the financial institution also still applies interest preference. Investment decision is an important factor in the company management because it will give the company profitability and it will influence the company value. (Karuna 2007, Laksmana dan Yang 2015).

The company investment fund can come from the company internal sources as well as from the external sources. If the fund from the internal sector is considered inadequate, the company can get investment fund from external sources, such as loan or leverage. As can be seen from the research done by Anwar and Sun (2014), Aivazian et al. (2005), and Guney et al. (2011), they say that leverage can influence the investment decision. The importance of leverage as an investments fund of an agro-industry company is that it can make the 
company develop and grow better and also improve economy. Therefore, it is important to carry out further research about the effects of leverage on the investments of agro-industry companies in Indonesia.

\section{LITERATURE REVIEW}

According to Mangunwidjaja et al. (2001) and Turniasih and Dewi (2016) Agroindustry is an inter-disciplines activity that utilizes agriculture as a natural resource for industrial activities which include: industry of agricultural machinery and facilities; processing industry of agricultural products; and industry of agricultural services. In line with it, according to the Ministry of Finance (2014) the products of agricultural bases are coffee, cocoa, tobacco, paper and paper by-products, vegetable oil, furniture, milk, fruits, and sugar.

Objectively, conflict between shareholders and managers can create agency problems. Agency problems appear when the agents (management) work for principals (shareholders). Agency cost happens when the managers do not try to maximize the company value, and the shareholders charge a fee for monitoring the managers and curb their actions (Brealey et al. 2011). The Agency theory was established based on seven basic assumptions: personal interest, goal conflict, limited rationality, asymmetric information, superior efficiency, risk evasion, and information as commodity (Eisenhardt, 1989).

Aivazian et al. (2005) researched the effects of financial leverage on the company investments using data obtained from the financial information in industrial companies in Canada. The results showed that leverage had a negative influence on the company investments. The leverage influence became stronger on the company whose growth opportunities were lower compared to the company whose growth opportunities were higher.

Firth et al. (2012) carried out research on the cash flow investments with financing channel in a public company in China. The result showed that investments had a relation with the cash flow level. This result strengthened the research result by Cleary et al. (2007) for the companies in the US and by Guariglia and Yang (2016) for the companies in Britain. According to Firth et al. (2012) the existence of leverage, besides the shareholders, debt-holders will also monitor the performance of the company and the company business decision, including the company investment decision.

Lang et al. (1996) conducted research in the companies in Canada. The results of the research showed that leverage had significant positive impacts on the company investments. The negative impacts of leverage became stronger on the companies with low growth opportunities. Ahn et al. (2006) carried out research on association between leverage and investments in diversified companies. The samples used were obtained from all companies in Compustat tapes during the period 1982 until 1997. The results of the research showed that leverage had a negative impact on the company investments. The impact became stronger on the segment of $Q$ high value compared to $Q$ low value, and significantly bigger on the non-core segments compared to the core segments.

Ajide (2017) researched the influence of institutional quality and specific factors of the company on the non-finance company investments in Nigeria during the period 2002 until 2012. The result of the research showed that regulator quality, corruption, political stability, and control from corruption did not significantly influence the decision of company investmentsin Nigeria, while the company specific factor influenced the company investments in Nigeria. Significant cash flow had a positive impact on investments, while Tobin Q, Stock of Liq. Asset, and Sales had a negative impact. Leverage, however, did not give any impact on the company investments.

The objective of the research was to find out the effects of leverage on the investments decision in a manufacturing company of agro-industrial bases in Indonesia. Besides, the research also tried to find out the sensitivity of the company's growth rate towards leverage impacts on agro-industry company investments. 


\section{METHODS OF RESEARCH}

Data used in this research were obtained from the financial reports of 17 manufacturing companies of agro-industrial bases listed in Indonesian Stock Exchange (BEI) from 2007 to 2016. The data obtained would be analyzed with descriptive statistics and panel data regression analysis. The panel data regression analysis was used to see the impacts of leverage on agro-industry companies in Indonesia. the dependent variable in this research was investment variable (I), while the independent variables were cash flow (CF), Tobin $Q$ (TQ), leverage (Lev), andsales (Sales).

$$
I_{i t}=\mathrm{\gamma}_{0}+\mathrm{\gamma}_{1} C F_{i t}+\mathrm{\gamma}_{2} T Q_{i t-1}+\mathrm{\gamma}_{3} \text { Lev }_{i t-1}+\mathrm{\gamma}_{4} \text { Sales }_{i t}+\varepsilon_{i t}
$$

Table 1 - Measuring the variables

\begin{tabular}{|c|c|}
\hline Variable & Notes \\
\hline I & Net investments $(\mathrm{I}) /$ lag from net fixed asset $(\mathrm{K})$ \\
\hline $\mathrm{CF}$ & $\begin{array}{l}\text { Earnings before extraordinary items plus depreciation and amortization divided from the book value } \\
\text { from the previous year asset }\end{array}$ \\
\hline $\mathrm{TQ}$ & $\begin{array}{l}\text { \{Total liability+market value from ordinary shares+ estimation of market value in preferred shares }\} / \\
\text { book value of the total asset }\end{array}$ \\
\hline LEV & Total liability/total asset \\
\hline SALES & Net sales (Sales)/ lag from fixed asset (K) \\
\hline DTQ & Dummy variables equals 1 if Tobin's $Q>1$, and 0 for the opposite \\
\hline
\end{tabular}

\section{RESULTS AND DISCUSSION}

Descriptive Statistics. Descriptive analysis was carried out in 17 manufacturing companies of agro-industrial bases listed in Indonesian Stock Exchange (BEI) from 2007 to 2016. The results of the descriptive statistic analysis are presented in Table 2.

Table 2 - Descriptive Statistics

\begin{tabular}{llllll}
\hline & $\mathrm{I}$ & CF & TQ & LEV & SALES \\
\hline Mean & 0.137548 & 0.262745 & 2.105823 & 0.484742 & 4.663675 \\
Median & 0.099151 & 0.053489 & 1.014452 & 0.504532 & 3.858885 \\
Maximum & 0.995376 & 3.584552 & 18.64041 & 0.893964 & 16.70822 \\
Minimum & -0.138492 & -1.174489 & 0.261931 & 0.071094 & 0.853344 \\
Std. Dev. & 0.176269 & 0.657566 & 3.283953 & 0.172361 & 3.234793 \\
\hline
\end{tabular}

Table 2 shows that investment average of agro-industry companies from 2007 to 2016 is 0.1375 with deviation standard value 0.1763 . The average value of cash flow is 0.2627 with deviation standard value 0.6576 . Then the value of average Tobin $Q$ is 2.1058 with deviation standard value 3.2840. The average leverage value of a company sample from 2007 to 2016 is 0.4847 with deviation standard value 0.1724 . Furthermore, the sales average value is 4.6637 with deviation standard value 3.2348 .

The Regression Analysis of Leverage Impacts on Agro-Industry Company Investments. In this research we used panel data regression analysis to see the impacts of leverage on agro-industry company investments listed in Indonesian Stock Exchange (BEI) from 2007 to 2016. In the panel data regression analysis there are three regression model approaches, namely pool least square (PLS), fixed effect model (FEM), andrandom effect model (REM). After Chow test and Hausman test were tested, based on the results obtained as can be seen in Table 3, it can be determined that random effect model (REM) is the regression model chosen for further analysis. TheR-Square value that shows goodness of fit obtained is 0.1773 .

Based on table 3, it can be seen that the variables of cash flow, Tobin Q, leverage, and sales have significant effects on the dependent variable of agro-industry company investments. The leverage variable has a significant negative impact on agro-industry company investments in Indonesia, with a coefficient value -0.2254 . The negative impact of 
leverage shows that the higher the leverage, the the company management are become more selective on their investments decision. This result is in line with the research conducted by Ahn et al. (2006), Aivazian (2003), Lang et al. (1996), Jensen (1986), Stulz (1990), and Grossman and Hart (1982). The presence of leverage makes the debtholder take parts in agency conflict between management and shareholders, and it functions to take control of management in making investments decision. Tobin $Q$, which becomes the proxy of the company growth or company opportunity to gets access of funding from capital markets. Tobin $Q$ has a positive impact on agro-industry company investments in Indonesia with coefficient value 0.0141 . The research result we obtain is in line with that by Chen (2014) and Aivazian et al. (2005), which shows that when Tobin Q increases, the company investments will also increase. The variable Sales as a control variable has a significant negative impact on the agro-industry company investments in Indonesia with a coefficient value 0.0096 . This result is in line with that of the previous research carried out by Aivazian et al (2005), Lang et al. (1996), and Prasetyantoko (2007), which shows that when sales increases, the company investments will also increase.

Table 3 - The effects of leverage on agro-industry company investments

\begin{tabular}{llll}
\hline Variable & PLS & FEM & REM \\
\hline Intercept & $0.163665^{* * *}$ & $0.275699^{* * *}$ & $0.206767^{* * *}$ \\
CF & $(3.548682)$ & $(3.449907)$ & $-(3.418058)$ \\
TQ & $-0.125070^{* * *}$ & $-0.123535^{* * *}$ & $(-5.215528)$ \\
Lev & $(-5.462193)$ & $(-4.244406)$ & $0.014115^{* *}$ \\
& $0.011671^{* * *}$ & $0.024275^{* *}$ & $(2.401584)$ \\
Sales & $(2.830909)$ & $(2.158832)$ & $-0.225365^{\star *}$ \\
& -0.108626 & $-0.446455^{\star * *}$ & $(-2.244232)$ \\
Chow test & $(-1.381850)$ & $(-3.192297)$ & $0.009596^{*}$ \\
Hausman test & $0.007467^{*}$ & $0.012780^{*}$ & $(1.783592)$ \\
& $(1.681321)$ & $(1.842588)$ & \\
R-Square & & & \\
Adjusted R-squared & 0.0003 & & 0.177263 \\
Durbin-Watson stat & 0.1499 & & 0.155027 \\
& & & 1.915035 \\
\hline
\end{tabular}

*** Significant on a $1 \%,{ }^{* *}$ Significant on $\alpha 5 \%,{ }^{*}$ Significant on a $10 \%$.

From the analysis results above, it can be concluded that cash flow has a positive impact on agro-industry company investments in Indonesia with a coefficient value -0.1311 . This result is different from some literatures such as Ajide (2017) Ahn et al. (2006), Chen et al (2013) and Aivazian et al. (2005). This is probably because of a financial constraint in the company when carrying out the company investments. This is in line with the result research conducted by Prasetyantoko (2007), in which it is concluded that manufacturing companies in Indonesia have financial constraints indicated by the negative relation between cash flow and investments.

The Effects of Company's Growth Rate on the Relation between Leverage and Company Investments. According to Aivazian et al. (2005) the company growth rate has given the leverage sensitivity a positive impact on the company investments. The company growth that is represented by Tobin $Q$ is the company opportunity to get access to good financing from capital markets. As for the company growth rate variable, the variable dummy (DTQ) is used, which means 1 if Tobin's $Q$ value is $>1$, and 0 if Tobin's $Q$ value is $<1$. The interaction variable between DTQ and Lev is used to see the role of company's growth rate in leverage on the agro-industry company investments in Indonesia. The following is its regression model.

$$
I_{i t}=\mathrm{\gamma}_{0}+\mathrm{\gamma}_{1} I_{i t-1}+\mathrm{\gamma}_{2} C F_{i t}+\mathrm{\gamma}_{3} T Q_{i t-1}+\mathrm{\gamma}_{4} \text { Lev }_{i t-1}+\mathrm{\gamma}_{5} \text { Sales }_{i t}+\mathrm{\gamma}_{6} D_{T Q_{i t-1}}+\mathrm{\gamma}_{7} D_{T Q_{i t-1}} * \text { Lev }_{i t-1}+\varepsilon_{i t}
$$


In the analysis of company's growth rate of the leverage impacts on the company investments, panel data regression analysis is used. The test results of Chow test and Hausman test show that REM model is the chosen one. The R-Square value shows that the goodness of fit obtained is 0.1802 .

Table 4 - The effects of company's growth rate in leverage on the company investments

\begin{tabular}{|c|c|c|c|}
\hline Variable & PLS & FEM & REM \\
\hline Intercept & $\begin{array}{l}0.183598^{\star \star \star} \\
(3.136137)\end{array}$ & $\begin{array}{l}0.306645^{\star \star \star} \\
(3.562464)\end{array}$ & $\begin{array}{l}0.229311^{* * *} \\
(3.378595)\end{array}$ \\
\hline CF & $\begin{array}{l}-0.122112^{\star * *} \\
(-5.264648)\end{array}$ & $\begin{array}{l}-0.122245^{* * *} \\
(-4.178999)\end{array}$ & $\begin{array}{l}-0.129557^{* * *} \\
(-5.177212)\end{array}$ \\
\hline TQ & $\begin{array}{l}0.008351 \\
(1.463514)\end{array}$ & $\begin{array}{l}0.025483^{* *} \\
(2.100944)\end{array}$ & $\begin{array}{l}0.013171^{*} \\
(1.920912)\end{array}$ \\
\hline Lev & $\begin{array}{l}-0.147369 \\
(-1.481042)\end{array}$ & $\begin{array}{l}-0.512616^{* * *} \\
(-3.273613)\end{array}$ & $\begin{array}{l}-0.262357^{* *} \\
(-2.290262)\end{array}$ \\
\hline Sales & $\begin{array}{l}0.007471^{*} \\
(1.666559)\end{array}$ & $\begin{array}{l}0.012486^{*} \\
(1.785641)\end{array}$ & $\begin{array}{l}0.009220^{*} \\
(1.730225)\end{array}$ \\
\hline DTQ & $\begin{array}{l}-0.052041 \\
(-0.643907)\end{array}$ & $\begin{array}{l}-0.079495 \\
(-0.918755)\end{array}$ & $\begin{array}{l}-0.061924 \\
(-0.778676)\end{array}$ \\
\hline DTQ*Lev & $\begin{array}{l}0.168189 \\
(0.934928)\end{array}$ & $\begin{array}{l}0.187758 \\
(0.988287)\end{array}$ & $\begin{array}{l}0.137863 \\
(0.784058)\end{array}$ \\
\hline $\begin{array}{l}\text { Chow test } \\
\text { Hausman test }\end{array}$ & $\begin{array}{l}0.0003 \\
0.1088\end{array}$ & & \\
\hline $\begin{array}{l}\text { R-Square } \\
\text { Adjusted R-squared } \\
\text { Durbin-Watson stat }\end{array}$ & $\begin{array}{l}0.185711 \\
0.152247 \\
1.642867\end{array}$ & $\begin{array}{l}0.403665 \\
0.302747 \\
2.141967\end{array}$ & $\begin{array}{l}0.180227 \\
0.146537 \\
1.887944\end{array}$ \\
\hline
\end{tabular}

${ }^{* * *}$ Significant on $\alpha 1 \%,{ }^{* *}$ Significant on a $5 \%,{ }^{*}$ Significant on a $10 \%$.

Based on Table 4, it can be seen that the results do now show that the level of company's growth rate (DTQ) has impacts on company investments. The variable Tobin $Q$ as a proxy of company growth rate has a significant positive impact on the company investments. However, after the variable is made into dummy by separating samples that have Tobin $Q$ value above 1 and below 1, dummy Tobin $Q$ does not give any impact on the company investments. This shows that the level of company's growth rate does not affect the company investments.

The regression analysis results show that the interaction variable DTQ*Lev does not give any impact on investments, which means that the level of company's growth rate does not give the leverage sensitivity any impacts on the company investments. This result is different from the research carried out by Aivazian et al. (2005) and Ahn et al. (2006), which shows that the interaction variable of the level of company's growth rate with leverage has affected significantly on the company investments. The research results of Aivazian et al. (2005) show that the level of company's growth rate strengthens the leverage impacts on the company investments. The research result of Ahn et al. (2006), however, shows that the dummy interaction variable Tobin $Q$ with excess leverage has a positive impact on focused business investments and has a negative impact on diversified business investments. This is due to the financial constraints in the investing companies.

According to Ajide (2017) the company having financial constraints will get different impacts in the firm-specific impacts of the company financial condition on the company investments decision making. As can be seen from the research carried out by Ajide (2017) the research results obtained are not consistent with those of the previous research because of the financial constraints. Therefore, in this study, it is assumed that because of the financial constraints, the level of company's growth rate did not affect the company investments decision. 


\section{CONCLUSION}

This research shows that cash flow, Tobin $Q$, leverage, and sales have significant impacts on agro-industry company investments in Indonesia. Leverage has a negative impact on the company investments. This proves that the presence of leverage has made investments decision become tight. Cash flow has a negative impact on the company investments, which shows the existence of financial constraints when the company will invest. Tobin $Q$ and Sales have a positive impact on the company investments, which shows that the higher the value Tobin $Q$ and Sales, the bigger the investments. Furthermore, the research also shows that the level of company's growth rate does not affect the company investments, and the level of company's growth rate does not give any leverage impact on the company investments.

\section{REFERENCES}

1. Ahn, S., Denis, D. J., \& Denis, D. K. (2006). Leverage and investment in diversified firms. Journal of financial Economics, 79(2), 317-337.

2. Aivazian, V. A., Ge, Y., \& Qiu, J. (2005). The impact of leverage on firm investment: Canadian evidence. Journal of corporate finance, 11(1-2), 277-291.

3. Ajide, F. M. (2017). Firm-specific, and institutional determinants of corporate investments in Nigeria. Future Business Journal, 3(2), 107-118.

4. Anwar, S., \& Sun, S. (2015). Can the presence of foreign investment affect the capital structure of domestic firms?. Journal of corporate finance, 30, 32-43.

5. Brealey, R.A., Myers, S.C., \& Allen, F. 2011. Principles of Corporate Finance. Singapore (SGP): Mcgraw-Hill Education (Asia).

6. Chen, C., Li, L., \& Ma, M. L. (2014). Product market competition and the cost of equity capital: evidence from China. Asia-Pacific Journal of Accounting \& Economics, 21(3), 227-261.

7. Chen, R., El Ghoul, S., Guedhami, O., \& Wang, H. (2017). Do state and foreign ownership affect investment efficiency? Evidence from privatizations. Journal of Corporate Finance, 42, 408-421.

8. Cleary S, Povel P, Raith M. (2007). "The U-shaped investments curve: theory and evidence". J. Financ. Quant. Anal. Vol 42 No. 1, pp 1-40.

9. Departemen Perindustrian dan Perdagangan. 2000. Program dan Strategi Pembangunan Industri Kimia, Agro dan Hasil Hutan; Direktorat Jenderal Industri Kimia, Agro dan Hasil Hutan (IKAH) 2000-2004. Jakarta.

10. Departemen Perindustrian dan Perdagangan. 2005. Program dan Strategi Pembangunan Industri Kimia, Agro dan Hasil Hutan ; Direktorat Jenderal Industri Kima, Agro dan Hasil Hutan (IKAH) 2005-2009. Jakarta.

11. Eisenhardt, K. M. (1989). Agency theory: An assessment and review. Academy of management review, 14(1), 57-74.

12. Firth, M., Malatesta, P. H., Xin, Q., \& Xu, L. (2012). Corporate investment, government control, and financing channels: Evidence from China's Listed Companies. Journal of Corporate Finance, 18(3), 433-450.

13. Grossman, S. J., \& Hart, O. D. (1982). Corporate financial structure and managerial incentives. In The economics of information and uncertainty (pp. 107-140). University of Chicago Press.

14. Guariglia, A., \& Yang, J. (2016). A balancing act: managing financial constraints and agency costs to minimize investment inefficiency in the Chinese market. Journal of Corporate Finance, 36, 111-130.

15. Guney, Y., Li, L., \& Fairchild, R. (2011). The relationship between product market competition and capital structure in Chinese listed firms. International Review of Financial Analysis, 20(1), 41-51.

16. Jensen, M. C. (1986). Agency costs of free cash flow, corporate finance, and takeovers. The American economic review, 76(2), 323-329. 
17. Karuna, C. (2007). Industry product market competition and managerial incentives. Journal of accounting and economics, 43(2-3), 275-297.

18. Kementerian perindustrian. 2015. Rencana induk pembangunan industri nasional 20152035.http://www.kemenperin.go.id/ripin.pdf

19. Kementerian perindustrian. 2016. Hilirisasi pembangunan industri berbasis agro. Disampaikan pada rapat kerja kementerian perindustrian Tahun 2016. Jakarta 16-17 Februari 2016.

20. Kementrian keuangan. 2014. Laporan dampak asean economic community terhadap sektor industri dan jasa, serta tenaga kerja di Indonesia. [Diakses Pada: 2016 Nov 20]. Tersedia Pada: http://www.kemenkeu.go.id/sites/default/files/Kajian\%20Dampak\%20ASEAN.pdf\#page37

21. Kementrian perindustrian. 2016. Kinerja industri agro TW III dan Eksim.Direktorat Jendral Industri Agro. [Internet]. [diunduh 2016 Desember 10]. Tersedia pada: http://agro.kemenperin.go.id/3658-Kinerja-Industri-Agro.

22. Laksmana, I., \& Yang, Y. W. (2015). Product market competition and corporate investment decisions. Review of Accounting and Finance, 14(2), 128-148.

23. Lang, L., Ofek, E., \& Stulz, R. (1996). Leverage, investment, and firm growth. Journal of financial Economics, 40(1), 3-29.

24. Mangunwidjaja D, Suprihatin, Muslich, 2001. Agroindustri: peran, prospek dan perkembangannya di Indonesia. Institut Pertanian Bogor.

25. Prasetyantoko, A. (2007). Financing Constraint and Firm-Level Investment Following a Financial Crisis in Indonesia.

26. Prasetyantoko, A. (2007). Foreign Ownership and Firm Financing Constraint in Indonesia. University Library of Munich, Germany.

27. Stulz, R. (1990). Managerial discretion and optimal financing policies. Journal of financial Economics, 26(1), 3-27.

28. Susilowati, S. H. (2007). Peran Sektor Agroindustri dalam Perekonomian Nasional dan Pendapatan Rumah Tangga Pertanian. In Di dalam Seminar Nasional Dinamika Pembangunan Pertanian dan Pedesaan: Mencari Alternatif Arah Pengembangan Ekonomi Rakyat.

29. Turniasih, I., \& Dewi, N. K. (2016). Peranan Sektor Agroindustri Dalam Pembangunan Nasional. Jurnal Geografi Gea, 7(2).

30. Yusdja, Y., \& Iqbal, M. (2002). Kebijaksanaan Pembangunan Agroindustri dalam Analisis Kebijakan: Paradigma Pembangunan dan Kebijaksanaan Pengembangan Agroindustri. Monograph Series, (21). 